\title{
Lytic HSV-1 infection induces the multifunctional transcription factor Early Growth Response-1 (EGR-1) in rabbit corneal cells
}

\author{
Gautam R Bedadala', Jayavardhana R Palem², Lorna Graham', James M Hill ${ }^{3}$, Harris E McFerrin ${ }^{4}$ and \\ Shao-Chung Hsia ${ }^{1 *}$
}

\begin{abstract}
Background: Herpes simplex virus type-1 (HSV-1) infections can cause a number of diseases ranging from simple cold sores to dangerous keratitis and lethal encephalitis. The interaction between virus and host cells, critical for viral replication, is being extensively investigated by many laboratories. In this study, we tested the hypothesis that HSV-1 lytic infection triggers the expression of important multi-functional transcription factor Egr1. The mechanisms of induction are mediated, at least in part, by signaling pathways such as NF $\kappa \mathrm{B}$ and CREB.
\end{abstract}

Methods: SIRC, VERO, and 293HEK cell lines were infected with HSV-1, and the Egr-1 transcript and protein were detected by RT-PCR and Western blot, respectively. The localization and expression profile of Egr-1 were investigated further by immunofluorescence microscopy analyses. The recruitment of transcription factors to the Egr-1 promoter during infection was studied by chromatin immunoprecipitation (ChIP). Various inhibitors and dominant-negative mutant were used to assess the mechanisms of Egr-1 induction and their effects were addressed by immunofluorescence microscopy.

Results: Western blot analyses showed that Egr-1 was absent in uninfected cells; however, the protein was detected 24-72 hours post treatment, and the response was directly proportional to the titer of the virus used for infection. Using recombinant HSV-1 expressing EGFP, Egr-1 was detected only in the infected cells. ChIP assays demonstrated that NFKB and CAMP response element binding protein (CREB) were recruited to the Egr-1 promoter upon infection. Additional studies showed that inhibitors of NFKB and dominant-negative CREB repressed the Egr-1 induction by HSV-1 infection.

Conclusion: Collectively, these results demonstrate that Egr-1 is expressed rapidly upon HSV-1 infection and that this novel induction could be due to the NFKB/CREB-mediated transactivation. Egr-1 induction might play a key role in the viral gene expression, replication, inflammation, and the disease progression.

Keywords: Egr-1, HSV-1, lytic infection

\section{Background}

Herpes simplex virus type-1 (HSV-1) is a common pathogen with worldwide seroprevalence rates ranging from $50 \%$ to $90 \%$ [1-3]. It is a neurotropic virus that is in the subfamily of alpha herpesvirinae. Initial or primary infection with HSV-1 mostly occurs during childhood in mucoepithelial surfaces and is generally mild or

\footnotetext{
* Correspondence: vhsia@umes.edu

'Department of Pharmaceutical Sciences, University of Maryland Eastern

Shore School of Pharmacy, Princess Anne, MD, USA

Full list of author information is available at the end of the article
}

asymptomatic. Upon infection of epithelial cells, HSV-1 initiates lytic replication, and at the end of this cycle, the virus infects sensory neurons proximal to the site of primary infection. Virions can travel via retrograde axonal transport to the cell bodies of neurons in the trigeminal ganglia where lifelong latency is established [4]. The latent virions can reactivate due to unknown causes and prohibit subsequent lytic infections. The most common form of lytic infection is the cold sore or fever blister where viral replication takes place in the orofacial mucosa [5]. Infection of the brain leads to herpes 
encephalitis, a dangerous condition that can cause permanent neurological damage with high mortality [5]. Orofacial infection, although less threatening, represents the major route for transmission to a naive host.

In addition to encephalopathy and orofacial infection, HSV-1 also infects the eyes leading to 8 cases of herpetic keratitis per 100,000 population every year [6]. Keratitis refers to inflammation of corneal epithelium due to a number of irritants such as infections by viruses, bacteria, and fungi. Herpetic keratitis is the major cause of corneal blindness, with unilateral visual impairment occurring in at least one-third of patients with recurrent disease [7].

Lytic infections of HSV-1 are typically characterized by the entry of virus into the cell and translocation of the viral genome into the nucleus followed by replication and evasion of host defenses in order to disperse and persist in the environment. Gene expression of HSV-1 is tightly regulated in a cascade fashion. The three temporal classes of genes are designated immediate-early $(\alpha)$, early $(\beta)$ and late $(\gamma)$ genes [8]. There are five $\alpha$ genes, designated ICP0, ICP4, ICP22, ICP27, and ICP47. The $\alpha$ genes were defined by the presence of the cis element for induction by VP16, which interacts with cellular factors, including the protein Oct-1, a homeobox protein, to activate viral immediate early (IE) gene transcription in trans $[9,10]$. The expression of $\beta$ genes requires the expression of $\alpha$ genes, especially functional ICP4. ICP0 enhances the ability of ICP4 to trans-activate $\gamma$ genes [11]. The expression of $\gamma$ gene has been shown to be blocked by effective concentrations of DNA synthesis inhibitors [12]. All of these steps require interaction between viral and host components. The communication between virus and host factors is being investigated by many laboratories but is not understood completely, and identification of host factors that interact with the virus remains a challenge. Additional information will identify new drug targets for treatment and will aid in understanding the complex processes of initiation of HSV-1 latency and reactivation.

Our laboratory examined the hypothesis that HSV-1 infection of epithelial cells including a cell line from rabbit cornea rapidly induced the expression of the cellular transcription factor early growth response-1 (Egr1), also known as NGFI-a, Zif268, Krox24, TIS8, and ZENK. The Early Growth Response (EGR) family belongs to the $\mathrm{C} 2 \mathrm{H} 2$-type zinc-finger proteins [13-15]. Egr-1 functions as a convergence point for many signaling cascades and is known to play an important role in regulating inflammation, cell proliferation, and apoptosis [16]. Our previous transient cotransfection studies with promoter plasmids and Egr-1 expression vector showed that Egr-1 regulated HSV-1 ICP22 and ICP4 promoter activity [17]. In the present study, we demonstrate for the first time that Egr-1 protein is induced rapidly in cells such as SIRC and VERO upon infection. Using inhibitors of the transcription factors CREB and NF $\kappa \mathrm{B}$, we further investigate the mechanism by which HSV-1 induces Egr-1 activation

\section{Methods}

\section{Cells, viruses and culture conditions}

VERO (derived from kidney epithelial cells of the African Green Monkey) cells and HEK293 cells were grown in DMEM supplemented with 10\% FBS. SIRC (Rabbit cornea) cells obtained from ATCC (Cat\#: CCL-60) were grown in MEM supplemented with $10 \%$ FBS. The REEGFP strain of HSV-1 was used throughout the study [18]. Unless otherwise indicated, all viral infections were carried with a MOI of 5 for 1 hour.

\section{Western Blot analysis}

Protein extract was subjected to $10 \%$ sodium dodecyl sulfate polyacrylamide gel electrophoresis and transferred onto nitrocellulose membranes. The blots were blocked using PBS with 5\% (wt/vol) non-fat dry milk and washed in PBS. Rabbit anti-Egr-1 polyclonal antibody (Santa Cruz SC-110x) or cAMP response element binding (CREB) Ser-133 phosphorylation (Abcam\#ab32096) was used at a dilution of 1:1,000. Anti-aTubulin mouse antibody (Calbiochem, Cat\#: CP06, San Diego, CA) was added at a dilution of 1:10,000. The chemiluminiscent signal from the membranes was detected by Syngene GeneGnome HR Bioimaging system (Frederick, MD). The protocol was performed essentially as described by the manufacturer.

\section{Immunofluoroscence}

Approximately 20,000 cells were placed in a multi-chamber slide (Cat\# 354104 BD Falcon) with respective media one day before infection. The cells were pretreated for 3 hours with inhibitors Bay 11-7082 (Calbiochem\#196871) and NBD binding peptide (Calbiochem Cat\#: 480025) for the NFKB inhibition study. After infection cells were rinsed once with $2 \mathrm{ml}$ PBS for 5 min and fixed with 100\% methanol at $-20^{\circ} \mathrm{C}$. Slides were incubated with $2 \%$ normal blocking serum followed by incubation with primary antibody for Egr-1 (Millipore\# MAB10073) overnight at $4^{\circ} \mathrm{C}$. The slides were then incubated with fluorescent conjugated secondary antibody (Invitrogen cat\# A21424), at RT for $1 \mathrm{hr}$. Finally, the slides were mounted with fluorescent mounting medium containing DAPI. The expression of enhanced green fluorescent protein (EGFP), red fluorescence, and DAPI staining were accessed by an Olympus fluorescence microscope (IX71) coupled with an Olympus digital camera photo apparatus (DP71). Imaging analysis was performed by using Olympus DP controller software. 


\section{Reverse transcriptase PCR (RT-PCR)}

Total RNA was extracted from the cells using trizol reagent (Invitrogen). RT-PCR was performed using Superscript One-Step RT-PCR (Invitrogen) with $0.5 \mu \mathrm{g}$ of total RNA and primer set for reaction. Their sequences are as follows: Egr-1: 5'-AGA CCA GTT ACC CCA GCC AAA C-3'and 5'-AAA ATG TCA GTG TTC GGC GTG-3'; EGFP: 5'-GCA GAA GAA CGG CAT CAA GGT G-3' and 5'-TGG GTG CTC AGG TAG TGG TTG TC-3'. The reverse transcription/PCR reaction was carried out at $45^{\circ} \mathrm{C}$ for $20 \mathrm{~min}$ followed by 25 cycles of $94^{\circ} \mathrm{C}$ for $30 \mathrm{~s}, 55^{\circ} \mathrm{C}$ for $30 \mathrm{~s}$, and $68^{\circ} \mathrm{C}$ for $30 \mathrm{~s}$. The RT-PCR products were analyzed by $2 \%$ agarose gel electrophoresis.

\section{Chromatin Immunoprecipitation (ChIP) assays}

Cell monolayers were treated with $1 \%$ formaldehyde solution for $10 \mathrm{~min}$ at room temperature. Cells were then harvested and subjected to sonication. The lysed samples were centrifuged for $10 \mathrm{~min}$ at $13,000 \mathrm{rpm}$ at $4^{\circ}$ $\mathrm{C}$ and the supernatant was diluted 10-fold with RIPA buffer containing protease inhibitor. Immunoprecipitation was then performed with Dynabeads Protein A (Invitrogen, Cat\#: 100.01D) with antibodies against CREB (Abcam\#ab32096) and NFKB (Abcam\#ab7970). To analyze immunoprecipitated DNA, PCR amplification was performed with primers against Egr-1 promoter: 5'-TGG GGG GCT TCA CGT CAC TC-3' and 5'AAG TTC TGC GGC TGG ATC TCT C-3". The products were analyzed by $2 \%$ agarose gel electrophoresis.

\section{Transfection studies involving the dominant negative mutants of CREB}

Approximately 20,000 cells were placed in a multichamber slide (Cat\# 354104 BD Falcon) with respective media one day before transfection. The cells were cotransfected with phMGFP (Promega Cat \#E6421) and one of the vectors (pCMV-CREB133 or PCMV-KCREB) from the CREB dominant negative vector set (Clonetech Cat\# 631925) using lipofectamine (Invitrogen). fter 2 days, the cells were infected with virus $(\mathrm{MOI}=1)$ for 1 hour. The cells were then incubated in fresh medium for 24 hours. Immunofluorescence was carried out using anti-Egr-1 antibody as described above.

\section{Results}

\section{Egr-1 protein is induced by HSV-1 infection}

The expression of Egr1 was established first using the VERO cell line as the model for our study because HSV-1 lytic gene expression is well characterized in these cells [19-23]. Western blotting analysis showed that Egr-1 protein was not present in VERO cells but was induced upon infection and that its induction was enhanced with increased viral infection (Figure 1A). A time-course study revealed that detectable levels of Egr-1 protein were present at 24 hours post infection, and similar levels were detected at 48 and 72 hours post infection (Figure 1B). Our data also indicated that Egr-1 protein was induced in rabbit corneal cells SIRC under similar conditions (Figure 1C). In addition, human corneal cell line HCE-2 was sufficient to produce Egr-1 upon HSV-1 infection (data not shown). However, Egr-1 was not inducible in HEK293 cells. Endogenous Egr-1 was present in uninfected 293HEK cells and the production was not stimulated by viral infection (Figure 1D). To further confirm the induction of Egr-1 by HSV-1, immunofluorescence staining was performed on infected cells. A recombinant HSV-1 constitutively expressing EGFP was used to infect the cells followed by fixation, blocking, and incubation with primary and secondary Egr-1 antibody (shown in red). The results supported the previous observation that Egr-1 protein (red) was co-expressed only in the cells infected with EGFP virus (green) (Figure 2). Together, these results strongly indicated that Egr1 protein was induced by HSV-1 infection.

\section{Egr-1 mRNA was detected at 1 hour post infection}

RT-PCR assays were used to analyze Egr-1 mRNA transcript expression upon infection. Interestingly, results showed that Egr-1 mRNA was produced as early as 1 hour post infection and a higher concentration of Egr-1 mRNA was observed 3 hours post infection (Figure 3). To address whether viral replication was necessary for Egr-1 production, the same analyses were conducted in the presence of acyclovir (ACV, $50 \mu \mathrm{M})$; the results indicated that viral replication was not required for Egr1 mRNA expression (Figure 3). These results demonstrated that HSV-1 infection increased Egr1 mRNA transcript expression which occurred immediately after viral inoculation.

\section{NFKB and pCREB were recruited to the Egr1 promoter upon infection}

The Egr-1 promoter exhibits several transcription factor binding sites such as NFKB [24] and CREB $[25,26]$. NFкB has been shown to interact with Egr-1 promoter $[27,28]$. ChIP assays were performed 24 hours post infection to examine the recruitment of NFKB and pCREB to the Egr1 promoter by HSV-1 infection. The results indicated that $\mathrm{NF \kappa B}$ and $\mathrm{pCREB}$ were recruited to the Egr-1 promoter upon infection in SIRC cells (compare Figure 4A, lanes 1 and 2). This type of recruitment was not seen in HEK293 cells, which exhibited no Egr1 induction upon infection (compare Figure 4A, lanes 3 and 4). Additional infection experiments showed increase in PCREB protein level during HSV-1 infection (Figure 4B, lane 2). These observations suggested that 


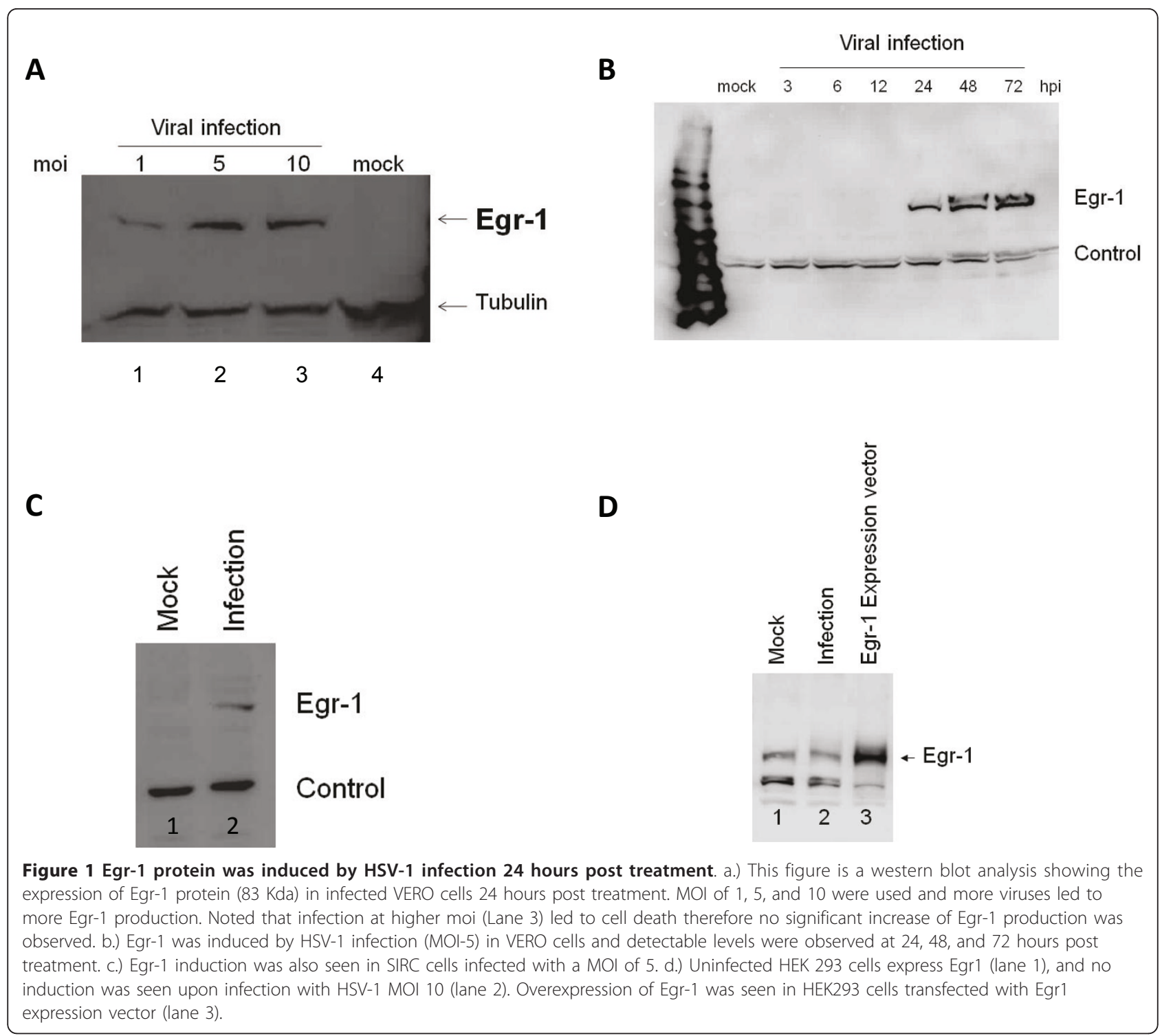

$\mathrm{NF} \kappa \mathrm{B}$ and pCREB could play roles in regulating HSV-1mediated Egr1 expression.

\section{Dominant-negative CREB decreased the Egr-1 induction observed upon infection}

Immunofluorescent analyses were performed to investigate if CREB participated in Egr1 induction. Following transfection with two dominant negative isoforms of CREB, pCREB 133 or pKCREB, the number of green fluorescent cells observed was similar after 2 days, indicating that transfection efficiency was equivalent (Figure $5 \mathrm{~A}$ ). Additional data showed that the use of dominant negative CREB inhibited the induction of Egr-1 (Figure $5 \mathrm{C}$ and $5 \mathrm{D}$ ) when compared to the GFP control (Figure 5B). Plasmid pCMV-CREB133 encodes a mutated form of CREB, blocking cAMP-induced transcription, and preventing CREB phosphorylation at S133. Plasmid pCMV-KCREB also encodes a mutated form of CREB, blocking CAMP-induced transcription. These results indicated that CREB was involved in the virus-mediated Egr1 expression.

\section{NFKB inhibition reduced Egr-1 expression by infection}

The NFкB inhibitor Bay11-7082 (Calbiochem, San Diego, CA) specifically targets the TNF- $\alpha$-inducible phosphorylation of $\mathrm{I} \kappa \mathrm{B} \alpha$, irreversibly inhibiting and decreasing expression of NF $\kappa \mathrm{B}$ [29]. NBD binding peptide is a cell-permeable fusion peptide that inhibits cytokine-induced NF- $\kappa \mathrm{B}$ activation and NF- $\kappa \mathrm{B}$-dependent gene expression [30]. Immunofluorescence studies showed that Bay 11-7082 (Figure 6B), and NBD binding peptide (Figure 6C) have a significant inhibitory effect 


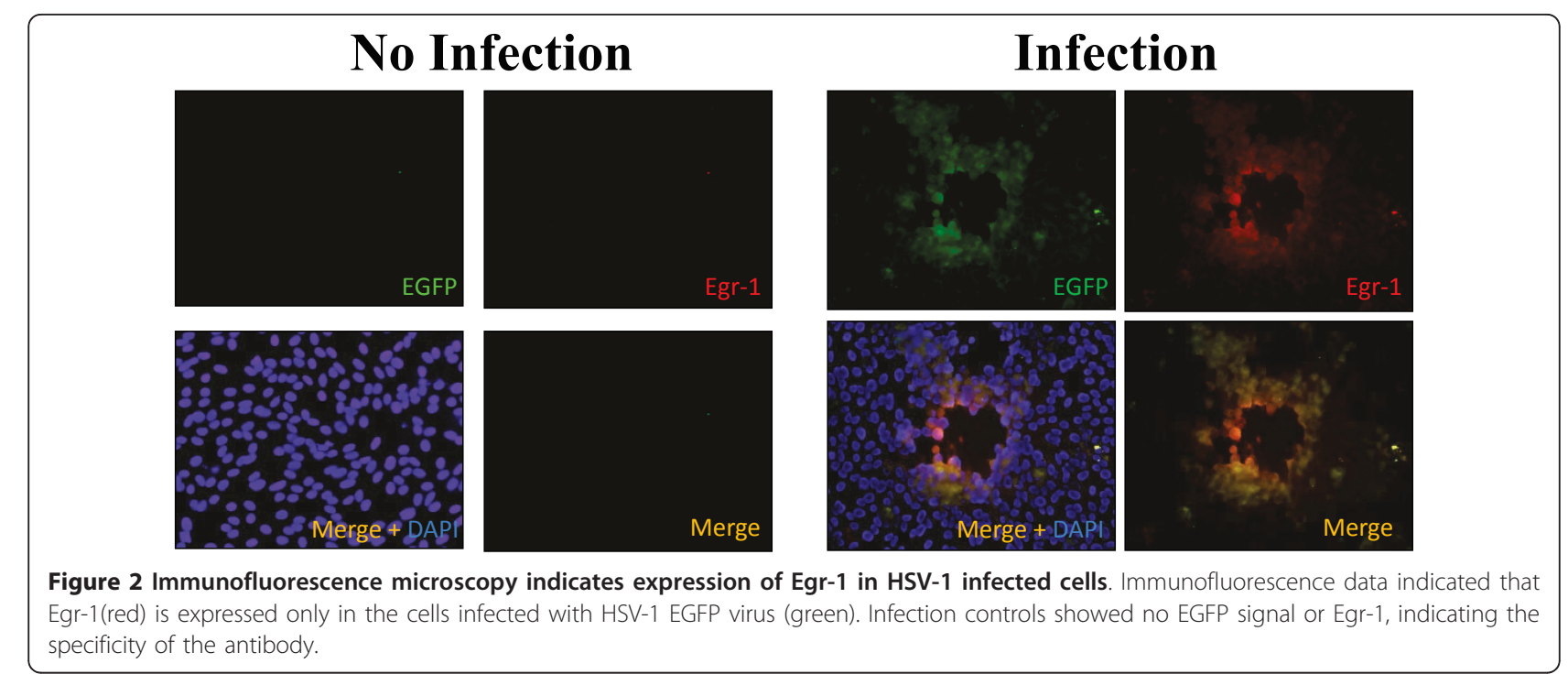

on Egr1 induction when compared to control (Figure $6 \mathrm{~A})$. These results demonstrated that $\mathrm{NF} \kappa \mathrm{B}$ participated in the induction of Egr1 upon infection.

\section{Discussion}

Egr-1 is involved in the gene expression and the replication of several viruses such as Epstein Barr virus [31,32], HSV-1 [17,33,34], JC virus [35], orthopox virus [36], murine corona virus [37], rabies virus [38,39], borna disease virus [39], human foamy virus [40], Japanese encephalitis virus [38], HTLV-I [41,42] and HTLV-II [42]. In most cases, Egr-1 was induced after the virus targeted neural cells and lymphocytes. Our results have demonstrated an induction of Egr-1 protein upon HSV-1 infection in epithelial cells such as VERO and SIRC (a corneal cell line). This observation suggests that Egr-1

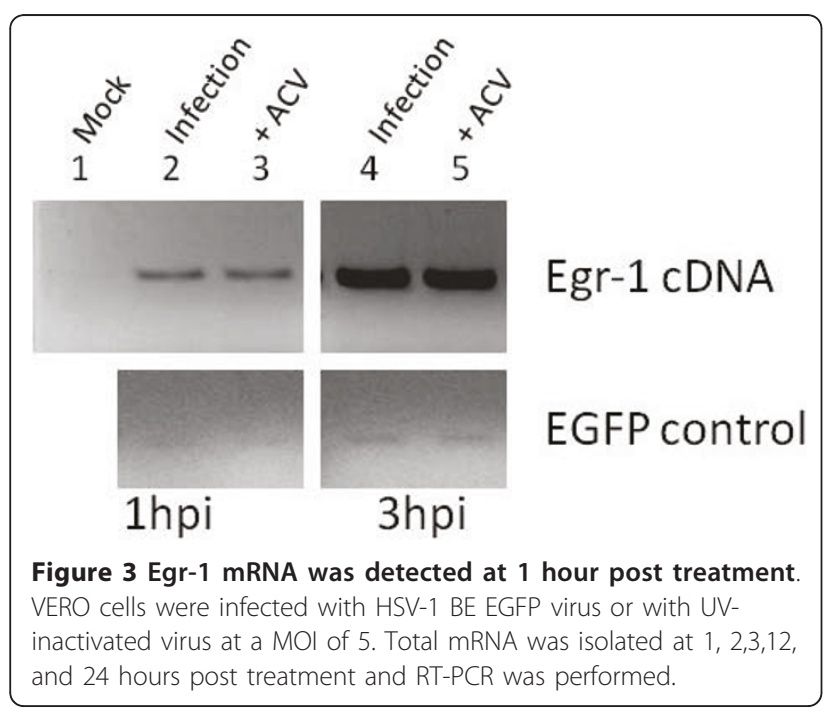

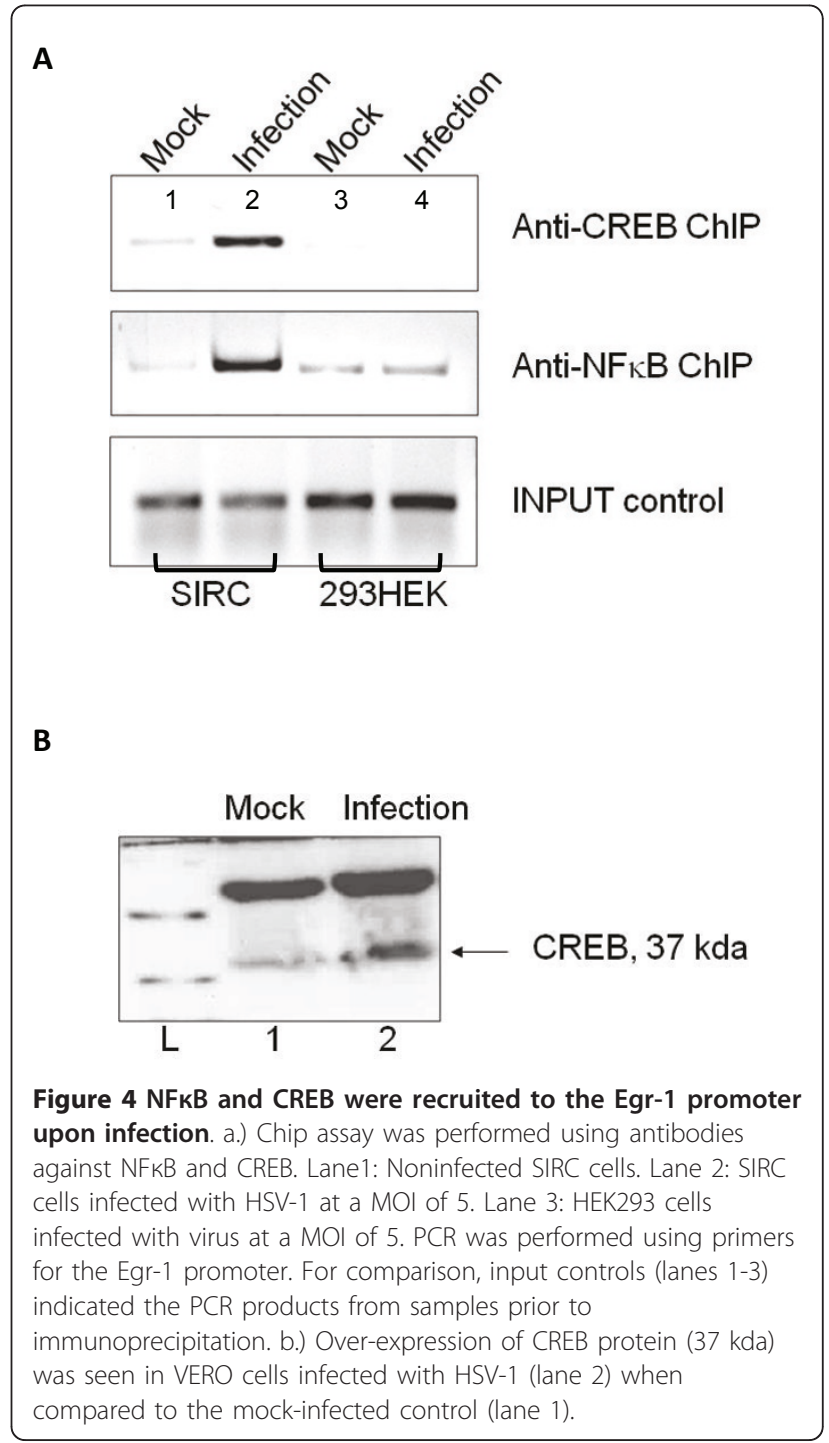


A

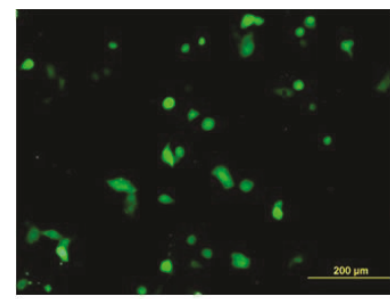

GFP+ control

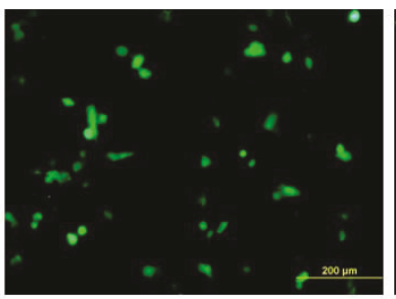

GFP+ pCREB133

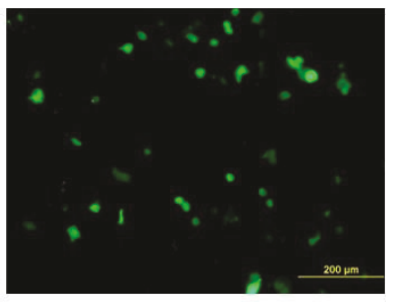

GFP+pKCREB
B Control

GFP

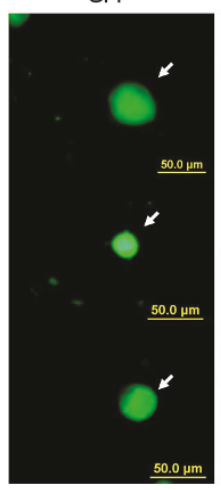

Egr-1

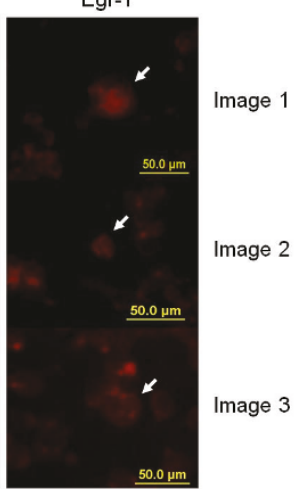

C

PCREB133

GFP

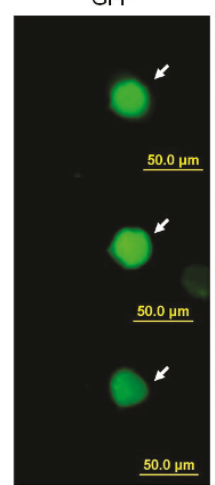

Egr-1

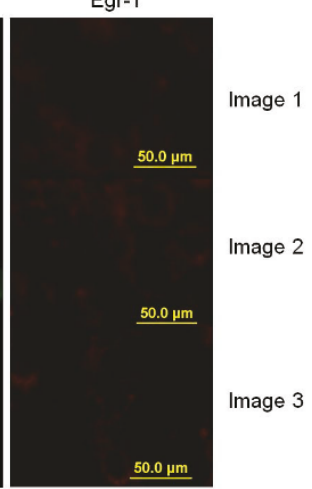

D PKCREB

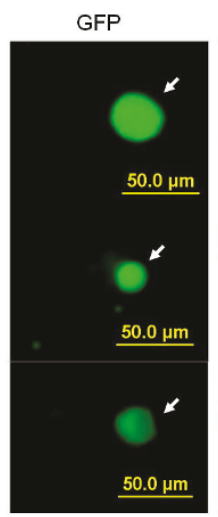

Egr-1

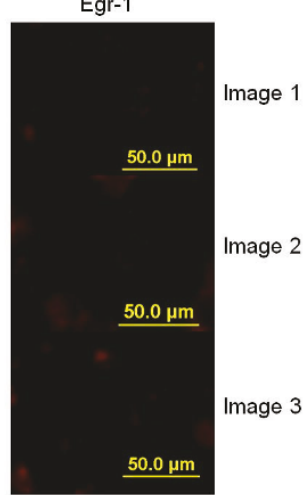

Figure 5 Dominant negative CREB inhibited the induction of Egr-1 upon HSV-1 infection. VERO cells were transfected with phMGFP alone and in combination with CREB dominant negative vectors pCREB133 or pKCREB. a.) The transfection efficiency of the three groups is similar as shown by the number of GFP-positive cells. b.) Cells infected with a control vector show induction of Egr-1 protein (red) whereas cells infected with the dominant negative mutants, CREB133(c) or KCREB (d) do not show the induction of the Egr-1 protein.

could play a role in host cellular responses to HSV-1 lytic infection.

Several pathways are known to regulate the induction of Egr-1 including p38/MAPK [43], JNK [44], MEK/ERK [45], CREB pathway [46], and NFKB activation [27,28]. By inhibiting the pathways known to be involved in Egr1 induction, we determined that $\mathrm{NFKB}$ and CREB play roles in Egr1 expression induced by HSV-1. CREB is activated and stabilized by HSV-1 ICP10 and can modulate viral-induced apoptosis [47]. Studies have reported the presence of $\mathrm{NF}_{\mathrm{K}} \mathrm{B}$ regulatory sequence [24] and CRE [25] in the human Egr-1 promoter. Transient activation of $\mathrm{NF}_{\mathrm{KB}}$ during the first few minutes of HSV1 infection has been reported [48,49]. In addition, most of the up-regulated mRNA upon infection was NFкBdependent [50]. Furthermore, NFкB-dependent gene expression is directly related to a number of stressinduced activities in eukaryotic cells [51]. Since Egr-1 is induced by stress and is known to control a variety of divergent cellular responses, it is possible that this induction is NFкB-dependent. Therefore from the host cell standpoint, viral infection can be considered as a stress and Egr1 is rapidly induced to turn on various cellular responses.

Our previous study showed that Egr1 can bind to the Egr1 binding element (EBE) located in the intron of ICP22 and thus regulate the activity of both ICP22 and ICP4 [17]. Since Egr1 is expressed in neural tissues, it could play a role in the maintenance of latency and subsequent reactivation. In addition, our preliminary studies revealed that Egr1 induced by viral infection was sufficient to interact with the ICP22 EBE during the lytic infection of SIRC and the over-expression of Egr-1 enhanced HSV-1 gene expression, replication, and release of infectious viruses (unpublished data). Together, these results suggest the involvement of Egr-1 in HSV-1 gene expression/replication via regulation of $\alpha$-genes. Recombinant virus over-expressing Egr-1 and stable cell lines containing siRNA repressing Egr-1 are being constructed to further investigate the roles of Egr1 during HSV-1 lytic infections.

It is not known which viral proteins are required for Egr-1 induction. It is likely that the binding of the viruses to the cell surface is sufficient to trigger the 

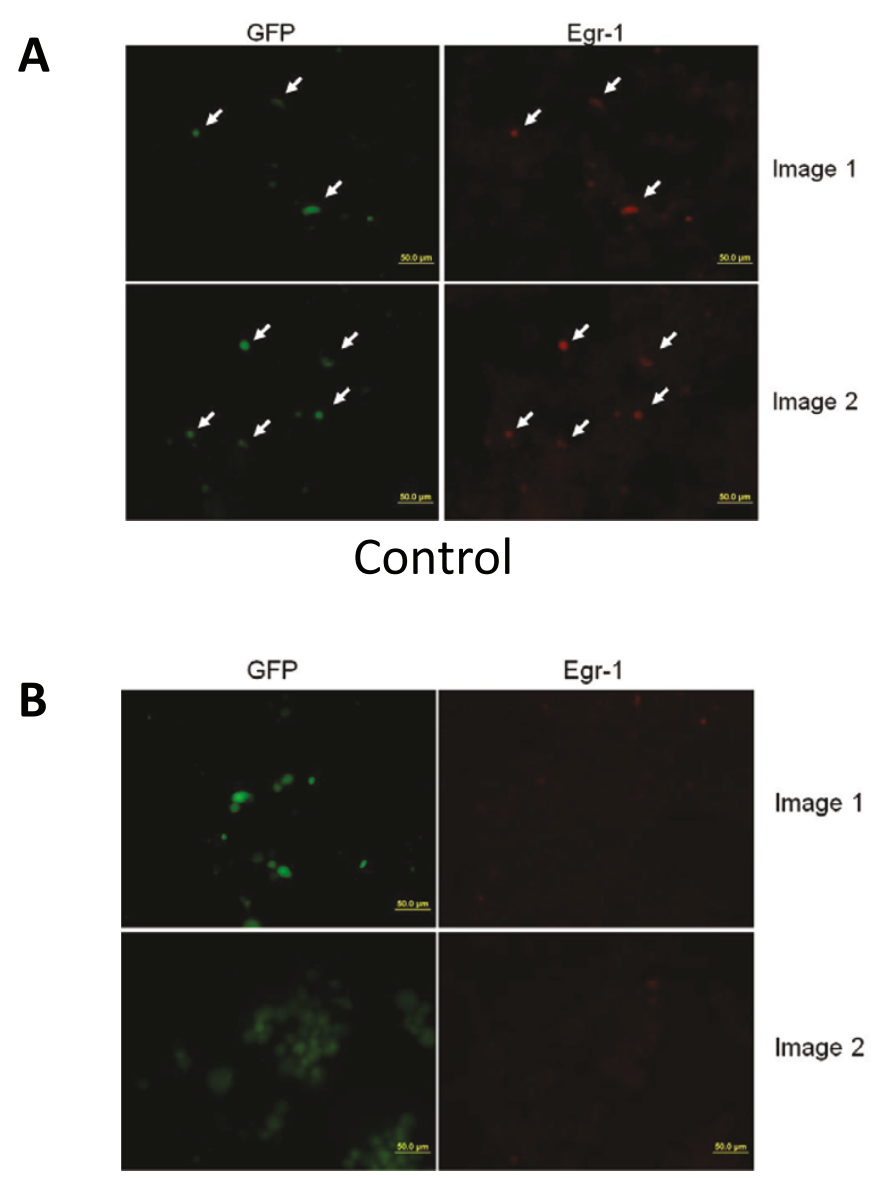

Bay 11-7082

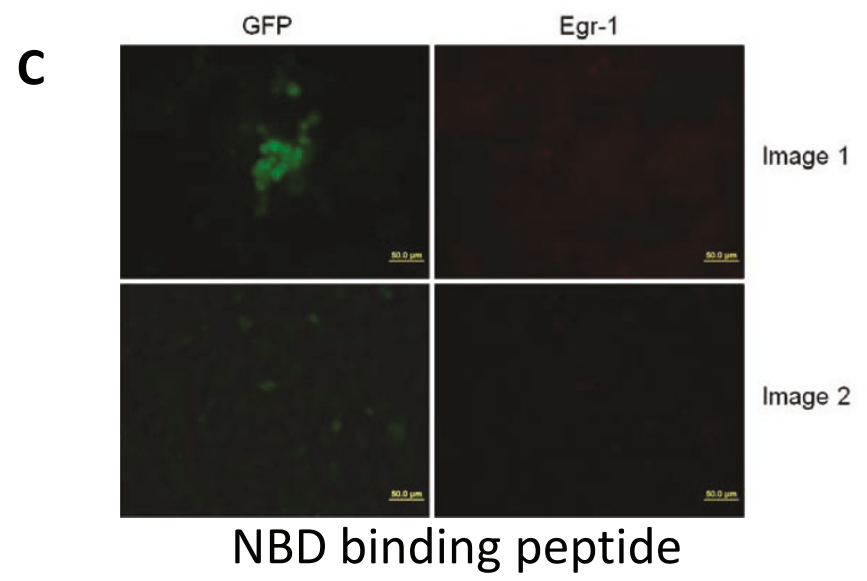

Figure 6 NFKB inhibitors abolished the induction of Egr-1 upon infection. Egr-1 expression was not induced in cells pretreated with $1 \mu \mathrm{M}$ of BAY 11-7082 (b) or $10 \mu \mathrm{M}$ NBD binding peptide (c) after infection with HSV-1 compared the control (a)

expression of Egr-1. Viral binding to the target cell is mediated by envelope glycoprotein $\mathrm{gB}, \mathrm{gC}$, or $\mathrm{gD}$ and the entry is mediated by $\mathrm{gD}$ to one of the cell surface receptors, such as the Herpes Virus Entry Mediator
(HVEM)), heparan sulfate, nectin-1/2, and cell adhesion molecules from the immunoglobulin superfamily [52]. HVEM belongs to the superfamily of TNF (tumor necrosis factor)/NGF (nerve growth factor) receptors 
[53], and has been identified independently as TR2 (TNF receptor like-2) [54]. The Egr-1 gene can be regulated by TNF [55] and NGF [56] in cultured cells, and NFкB can be activated by the gD/HVEM [57]. Therefore, Egr-1 induction quite possibly can be correlated to the binding of viral glycoprotein to HVEM or other cellular surface receptors. Additional experiments are required to determine the induction mechanisms of Egr1 by viral infection.

\section{Conclusion}

In summary, we have shown for the first time that Egr1 can be induced rapidly by HSV-1 lytic infection in epithelial cells such as VERO and SIRC. This induction may be due to transactivation by the NFкB and/or CREB-mediated signaling cascades. The Egr1 induced by HSV-1 in corneal cells could have implications in viral pathogenesis, inflammation, and disease progression. More experiments to determine the role of Egr-1 are underway, especially in other models of infection.

\section{List of Abbreviations}

ACV: acyclovir; ChIP: chromatin immunoprecipitation; CREB: CAMP response element binding protein; DAPI: 4',6-diamidino-2-phenylindole; DMEM: Dulbecco's modified Eagles medium; EBE: Egr1 binding element; EGR: Early growth response; FBS: fetal bovine serum; GFP: green fluorescent protein; HVEM: herpes virus entry mediator; NBD: NEMO-binding domain; NGF: nerve growth factor; PBS: phosphate buffered saline; RIPA:

radioimmunoprecipitation assay; SIRC: Statens Seruminstitut Rabbit Cornea; TNF: tumor necrosis factor; TR2: TNF-receptor like-2; VERO: derived from kidney epithelial cells of the African green monkey.

\section{Acknowledgements}

This publication was made possible by NIH Grant R15EY020803 to SVH. Its contents are solely the responsibility of the authors and do not necessarily represent the official views of $\mathrm{NIH}$. We thank Ms. Trisha Chiasson for manuscript editing. Support from University of Maryland Eastern Shore is acknowledged. LG is supported by R15EY020803. JRP is supported by NCRR Grant P20RR016456. JMH is supported in part by NEI EY006311, Research to Prevent Blindness Senior Scientific Investigator Award, and LSU Eye Center Core Grant NEI EY02377.

\section{Author details \\ 'Department of Pharmaceutical Sciences, University of Maryland Eastern Shore School of Pharmacy, Princess Anne, MD, USA. ${ }^{2}$ Department of Basic Pharmaceutical Sciences, University of Louisiana Monroe School of Pharmacy, Monroe, LA, USA. ${ }^{3}$ Department of Ophthalmology, Louisiana State University Health Sciences Center, New Orleans, LA, USA. ${ }^{4}$ Department of Biology, Xavier University of Louisiana, New Orleans, LA, USA.}

\section{Authors' contributions}

GRB established the experimental protocols, performed the infection and immunofluorescent microscopy, completed the Western blot analyses, composed the draft of the manuscript, etc. JRP performed the RT-PCR, assisted the preparation of manuscript, performed the transfection experiments, confirmed the RT-PCR results, and maintained the cell cultures. LG performed the RT-PCR, Western blot analysis and repeated the transfection experiments. HEM and JMH participated in the experimental design, prepared the expression vectors, discussed the experimental data, conceived the strategic plan, and participated in the manuscript preparation. SVH initiated the project, identified the Egr-1 induction, directed all the experimental approaches, analyzed the preliminary data, supervised the work, and prepared the manuscript. All authors read and approved the final manuscript.

\section{Competing interests}

The authors declare that they have no competing interests.

Received: 24 February 2011 Accepted: 27 May 2011

Published: 27 May 2011

\section{References}

1. Looker KJ, Garnett GP: A systematic review of the epidemiology and interaction of herpes simplex virus types 1 and 2. Sex Transm Infect 2005, 81(2):103-7.

2. Howard M, Sellors JW, Jang D, Robinson NJ, Fearon M, Kaczorowski J, Chernesky M: Regional distribution of antibodies to herpes simplex virus type 1 (HSV-1) and HSV-2 in men and women in Ontario, Canada. J Clin Microbiol 2003, 41(1):84-9.

3. Smith JS, Robinson NJ: Age-specific prevalence of infection with herpes simplex virus types 2 and 1: a global review. J Infect Dis 2002, 186(Suppl 1):S3-28.

4. Taylor TJ, Brockman MA, McNamee EE, Knipe DM: Herpes simplex virus. Front Biosci 2002, 7:d752-64.

5. Lachmann R: Herpes simplex virus latency. Expert Rev Mol Med 2003, 5(29):1-14.

6. Young RC, Hodge DO, Liesegang TJ, Baratz KH: Incidence, recurrence, and outcomes of herpes simplex virus eye disease in Olmsted County, Minnesota, 1976-2007: the effect of oral antiviral prophylaxis. Arch Ophthalmol 2010, 128(9):1178-83.

7. Claoue CM, Menage MJ, Easty DL: Severe herpetic keratitis. I: Prevalence of visual impairment in a clinic population. Br J Ophthalmol 1988, 72(7):530-3

8. Fenwick M, Roizman B: Regulation of herpesvirus macromolecular synthesis. VI. Synthesis and modification of viral polypeptides in enucleated cells. J Virol 1977, 22(3):720-5.

9. Jordan R, Schang L, Schaffer PA: Transactivation of herpes simplex virus type 1 immediate-early gene expression by virion-associated factors is blocked by an inhibitor of cyclin-dependent protein kinases [In Process Citation]. J Virol 1999, 73(10):8843-7.

10. Zachos $G$, Clements $B$, Conner J: Herpes simplex virus type 1 infection stimulates p38/c-Jun $\mathrm{N}$-terminal mitogen-activated protein kinase pathways and activates transcription factor AP-1. J Biol Chem 1999, 274(8):5097-103.

11. Chen J, Silverstein S: Herpes simplex viruses with mutations in the gene encoding ICP0 are defective in gene expression. J Virol 1992, 66(5):2916-27.

12. Costa RH, Devi BG, Anderson KP, Gaylord BH, Wagner EK: Characterization of a major late herpes simplex virus type 1 mRNA. J Virol 1981, 38(2):483-96.

13. Swirnoff AH, Milbrandt J: DNA-binding specificity of NGFI-A and related zinc finger transcription factors. Mol Cell Biol 1995, 15(4):2275-87.

14. Russo MW, Sevetson BR, Milbrandt J: Identification of NAB1, a repressor of NGFI-A- and Krox20-mediated transcription. Proc Natl Acad Sci USA 1995, 92(15):6873-7.

15. Milbrandt J: A nerve growth factor-induced gene encodes a possible transcriptional regulatory factor. Science 1987, 238(4828):797-9.

16. Thiel G, Cibelli G: Regulation of life and death by the zinc finger transcription factor Egr-1. J Cell Physiol 2002, 193(3):287-92.

17. Bedadala GR, Pinnoji RC, Hsia SC: Early growth response gene 1 (Egr-1) regulates HSV-1 ICP4 and ICP22 gene expression. Cell Res 2007, 17(6):546-55.

18. Kaufman HE, Varnell ED, Thompson HW: Cidofovir and experimental herpetic stromal disease. Arch Ophthalmol 1999, 117(7):925-8.

19. Spear $P G$, Roizman B: Proteins specified by herpes simplex virus. V. Purification and structural proteins of the herpesvirion. J Virol 1972, 9(1):143-59.

20. Honess RW, Roizman B: Proteins specified by herpes simplex virus. XIII. Glycosylation of viral polypeptides. J Virol 1975, 16(5):1308-26.

21. Honess RW, Roizman B: Regulation of herpesvirus macromolecular synthesis: sequential transition of polypeptide synthesis requires functional viral polypeptides. Proc Natl Acad Sci USA 1975, 72(4):1276-80. 
22. Honess RW, Roizman B: Regulation of herpesvirus macromolecular synthesis. I. Cascade regulation of the synthesis of three groups of viral proteins. J Virol 1974, 14(1):8-19.

23. Honess RW, Roizman B: Proteins specified by herpes simplex virus. XI. Identification and relative molar rates of synthesis of structural and nonstructural herpes virus polypeptides in the infected cell. J Virol 1973, 12(6):1347-65.

24. Aicher WK, Sakamoto KM, Hack A, Eibel H: Analysis of functional elements in the human Egr-1 gene promoter. Rheumatol Int 1999, 18(5-6):207-14.

25. Sakamoto KM, Bardeleben C, Yates KE, Raines MA, Golde DW, Gasson JC: 5' upstream sequence and genomic structure of the human primary response gene, EGR-1/TIS8. Oncogene 1991, 6(5):867-71.

26. Schwachtgen JL, Campbell CJ, Braddock M: Full promoter sequence of human early growth response factor-1 (Egr-1): demonstration of a fifth functional serum response element. DNA Seq 2000, 10(6):429-32.

27. Cogswell PC, Mayo MW, Baldwin AS Jr: Involvement of Egr-1/RelA synergy in distinguishing $T$ cell activation from tumor necrosis factor-alphainduced NF-kappa B1 transcription. J Exp Med 1997, 185(3):491-7.

28. Chapman NR, Perkins ND: Inhibition of the RelA(p65) NF-kappaB subunit by Egr-1. J Biol Chem 2000, 275(7):4719-25.

29. Pierce JW, Schoenleber R, Jesmok G, Best J, Moore SA, Collins T, Gerritsen ME: Novel inhibitors of cytokine-induced IkappaBalpha phosphorylation and endothelial cell adhesion molecule expression show anti-inflammatory effects in vivo. J Biol Chem 1997, 272(34):21096-103.

30. Pande V, Ramos MJ: NF-kappaB in human disease: current inhibitors and prospects for de novo structure based design of inhibitors. Curr Med Chem 2005, 12(3):357-74.

31. Calogero A, Cuomo L, D'Onofrio M, de Grazia U, Spinsanti P, Mercola D, Faggioni A, Frati L, Adamson ED, Ragona G: Expression of Egr-1 correlates with the transformed phenotype and the type of viral latency in EBV genome positive lymphoid cell lines. Oncogene 1996, 13(10):2105-12.

32. Chang Y, Lee HH, Chen YT, Lu J, Wu SY, Chen CW, Takada K, Tsai CH: Induction of the early growth response 1 gene by Epstein-Barr virus lytic transactivator Zta. J Virol 2006, 80(15):7748-55.

33. Tatarowicz WA, Martin CE, Pekosz AS, Madden SL, Rauscher FJ, Chiang SY, Beerman TA, Fraser NW: Repression of the HSV-1 latency-associated transcript (LAT) promoter by the early growth response (EGR) proteins: involvement of a binding site immediately downstream of the TATA box. J Neurovirol 1997, 3(3):212-24.

34. Chen SH, Yao HW, Chen IT, Shieh B, Li C: Suppression of transcription factor early growth response 1 reduces herpes simplex virus lethality in mice. J Clin Invest 2008, 118(10):3470-7.

35. Romagnoli L, Sariyer IK, Tung J, Feliciano M, Sawaya BE, Del Valle L, Ferrante P, Khalili K, Safak M, White MK: Early growth response-1 protein is induced by $\mathrm{JC}$ virus infection and binds and regulates the $\mathrm{JC}$ virus promoter. Virology 2008, 375(2):331-41.

36. Silva PN, Soares JA, Brasil BS, Nogueira SV, Andrade AA, de Magalhaes JC, Bonjardim MB, Ferreira PC, Kroon EG, Bruna-Romero O, Bonjardim CA: Differential role played by the MEK/ERK/EGR-1 pathway in orthopoxviruses vaccinia and cowpox biology. Biochem J 2006, 398(1):83-95.

37. Cai $Y$, Liu Y, Zhang $X$ : Induction of transcription factor Egr-1 gene expression in astrocytoma cells by Murine coronavirus infection. Virology 2006, 355(2):152-63.

38. Saha S, Rangarajan PN: Common host genes are activated in mouse brain by Japanese encephalitis and rabies viruses. J Gen Virol 2003, 84(Pt 7):1729-35.

39. Fu ZF, Weihe E, Zheng YM, Schafer MK, Sheng H, Corisdeo S, Rauscher FJ, Koprowski H, Dietzschold B: Differential effects of rabies and borna disease viruses on immediate-early- and late-response gene expression in brain tissues. J Virol 1993, 67(11):6674-81.

40. Wagner A, Doerks A, Aboud M, Alonso A, Tokino T, Flugel RM, Lochelt M: Induction of cellular genes is mediated by the Bel1 transactivator in foamy virus-infected human cells. J Virol 2000, 74(10):4441-7.

41. Fujii M, Niki T, Mori T, Matsuda T, Matsui M, Nomura N, Seiki M: HTLV-1 Tax induces expression of various immediate early serum responsive genes. Oncogene 1991, 6(6):1023-9.

42. Sakamoto KM, Nimer SD, Rosenblatt JD, Gasson JC: HTLV-I and HTLV-II tax trans-activate the human EGR-1 promoter through different cis-acting sequences. Oncogene 1992, 7(11):2125-30.
43. Johnson GL, Lapadat R: Mitogen-activated protein kinase pathways mediated by ERK, JNK, and p38 protein kinases. Science 2002, 298(5600):1911-2.

44. Kumahara E, Ebihara T, Saffen D: Nerve growth factor induces zif268 gene expression via MAPK-dependent and -independent pathways in PC12D cells. J Biochem 1999, 125(3):541-53.

45. Sgambato V, Pages C, Rogard M, Besson MJ, Caboche J: Extracellular signal-regulated kinase (ERK) controls immediate early gene induction on corticostriatal stimulation. J Neurosci 1998, 18(21):8814-25.

46. Mayer SI, Willars GB, Nishida E, Thiel G: Elk-1, CREB, and MKP-1 regulate Egr-1 expression in gonadotropin-releasing hormone stimulated gonadotrophs. J Cell Biochem 2008, 105(5):1267-78.

47. Perkins D, Pereira EF, Aurelian L: The herpes simplex virus type 2 R1 protein kinase (ICP10 PK) functions as a dominant regulator of apoptosis in hippocampal neurons involving activation of the ERK survival pathway and upregulation of the antiapoptotic protein Bag-1. J Virol 2003, 77(2):1292-305.

48. Patel A, Hanson J, McLean TI, Olgiate J, Hilton M, Miller WE, Bachenheimer SL: Herpes simplex type 1 induction of persistent NFkappa B nuclear translocation increases the efficiency of virus replication. Virology 1998, 247(2):212-22.

49. Mogensen TH, Paludan SR: Molecular pathways in virus-induced cytokine production. Microbiol Mol Biol Rev 2001, 65(1):131-50.

50. Esclatine A, Taddeo B, Evans L, Roizman B: The herpes simplex virus 1 UL41 gene-dependent destabilization of cellular RNAs is selective and may be sequence-specific. Proc Natl Acad Sci USA 2004, 101(10):3603-8.

51. Pahl HL: Activators and target genes of Rel/NF-kappaB transcription factors. Oncogene 1999, 18(49):6853-66.

52. Spear PG, Manoj S, Yoon M, Jogger CR, Zago A, Myscofski D: Different receptors binding to distinct interfaces on herpes simplex virus $\mathrm{gD}$ can trigger events leading to cell fusion and viral entry. Virology 2006, 344(1):17-24.

53. Montgomery RI, Warner MS, Lum BJ, Spear PG: Herpes simplex virus-1 entry into cells mediated by a novel member of the TNF/NGF receptor family. Cell 1996, 87(3):427-36.

54. Kwon OJ: The role of nitric oxide in the immune response of tuberculosis. J Korean Med Sci 1997, 12(6):481-7.

55. Cao XM, Guy GR, Sukhatme VP, Tan YH: Regulation of the Egr-1 gene by tumor necrosis factor and interferons in primary human fibroblasts. $J$ Biol Chem 1992, 267(2):1345-9.

56. DeFranco C, Damon DH, Endoh M, Wagner JA: Nerve growth factor induces transcription of NGFIA through complex regulatory elements that are also sensitive to serum and phorbol 12-myristate 13-acetate. Mol Endocrinol 1993, 7(3):365-79.

57. Sciortino MT, Medici MA, Marino-Merlo F, Zaccaria D, Giuffre-Cuculletto M, Venuti A, Grelli S, Mastino A: Involvement of HVEM receptor in activation of nuclear factor kappaB by herpes simplex virus 1 glycoprotein D. Cell Microbiol 2008, 10(11):2297-311.

\section{doi:10.1186/1743-422X-8-262}

Cite this article as: Bedadala et al:: Lytic HSV-1 infection induces the multifunctional transcription factor Early Growth Response-1 (EGR-1) in rabbit corneal cells. Virology Journal 2011 8:262.

\section{Submit your next manuscript to BioMed Central and take full advantage of:}

- Convenient online submission

- Thorough peer review

- No space constraints or color figure charges

- Immediate publication on acceptance

- Inclusion in PubMed, CAS, Scopus and Google Scholar

- Research which is freely available for redistribution 